\title{
The importance of tolerance for failure and risk-taking among insurance firms in hyperinflationary Zimbabwe
}

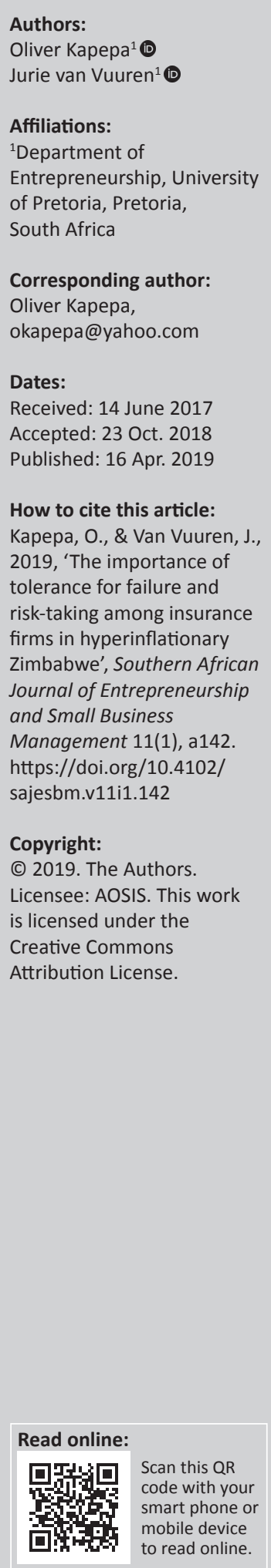

Background: At the dawn of the 21st century, Zimbabwe started moving towards dangerous levels of the infamous hyperinflation trajectory that made management of businesses a nightmare. Many businesses failed.

Aim: This study seeks to explore if entrepreneurship, and in particular the aspects of risktaking and tolerance of failure, could have saved the few companies that survived the menace that ravaged the insurance industries among many other sectors of the economy.

Setting: The study looks at this particular entrepreneurial behaviour of risk-taking among insurance companies in Zimbabwe during the hyperinflationary environment that ravaged and defied economic logic and fundamentals. Savings were being eroded at a pace faster than anywhere in the world ever before, taking a toll on businesses as they struggled to survive.

Methods: Using a survey sample of insurance companies in Zimbabwe, a quantitative approach was adopted. Questionnaires were used to extract data from participants to establish the nature and extent of risk-taking, and in particular tolerance for failure during this period. Therefore, tolerance of failure in corporate entities is discussed in this article as a critical aspect of risk-taking that enhances entrepreneurial innovation and ultimate prospects of corporate prosperity among insurance companies. A measure is developed to gauge the extent of tolerance of failure from the perspective of employees in the insurance industry in Zimbabwe.

Results: The benefit of tolerance of failure or the lack thereof was measured on the dimension of profitability and growth. Results revealed that tolerance of failure is a necessary entrepreneurial virtue that encourages knowledge acquisition by both experimental and experiential learning - a risk element that also spurs entrepreneurial innovation and ultimately encourages both profitability and growth of the business entity, if well managed.

Conclusion: The study concluded that firms that tolerate failure are more likely to be entrepreneurially innovative and perform better than those that are risk-averse and do not tolerate failure.

Keywords: Entrepreneurship; risk taking; tolarance of failure; insurance firms; entrepreneurial performance; Zimbabwe.

\section{Introduction}

To act entrepreneurially is neither a miracle nor is it merely necessitated by circumstances of deprivation or any conditions of living. It is an inevitable challenge - and one must encounter these challenges and failures unless one looks for a salaried job. In essence, entrepreneurship is about successes and failures, bearing in mind that a small start-up will have to compete with established giants for quality products in the same marketplace. Many firm managers might confess willingness to taking risks at some point, but few would consider tolerating failure as a risk worth taking. In fact, few would consider tolerance of failure as a risk rather than a potential loss of business. Yet, the ability to tolerate failure would determine the extent to which a firm is prepared to take risks and enhance its entrepreneurial behaviour for better performance. Even as it takes some measure of entrepreneurial endeavour for all business organisations to continue to exist (Kang 2013:25; Zimmerman 2010:1), the process of growing the business is always fraught with obstacles and risks as well as failures.

Equally, it requires the entrepreneurial prowess of some individuals in a firm, whether by themselves or collectively, to take their ventures across the famed Rubicon of success and remain at the top of the marketplace, regardless of the vagaries and hostilities of the business environment. The pressures to 
maintain this position are made even more acute by the observation that as businesses grow, they become averse to risk and failure, and they become too bureaucratic and lose their entrepreneurial spirit and capabilities (Christensen 2004; Haeng-Sun 2016; Johnson 2001), which does not augur well for ventures operating in a competitive marketplace. They also stop taking risks for fear of failure and protecting whatever little assets they have. Failure is not tolerated anymore as tolerance, it is feared, may lead to unanticipated harmful outcomes arising from taking such risks, notwithstanding the expertise, capital, assets and other available resources. Guillemette et al. (2015) explore the concept of risk assessment called the expected utility theory, which advances the notion that the extent to which risk is tolerated is accompanied and influenced by future benefits or losses. Failure tolerance becomes even more remote and perhaps more detrimental when hyperinflationary conditions prevail, such as existed in Zimbabwe from 2003 to 2008. Even as they grow, companies must continue, out of necessity, to take risks as a critical component of their entrepreneurial orientation (EO). Tolerance of failure is one such critical EO attribute for success.

The objective of this study was therefore to fully explore the significance of tolerance of failure to the survival of some insurance companies in the hyperinflationary environment of Zimbabwe. The study sought to hypothesise, broadly, that those insurance companies that overcame the hyperinflationary situation and were revitalised did so partly on the back of the extent of their tolerance of failure, especially with regard to their employees who eventually saw a rise in the levels of corporate entrepreneurial activity through innovations that ensued.

In pursuit of establishing factual solutions to these hypothetical statements, the study has depended upon both primary and secondary data. However, data were largely quantitatively analysed. The research used a relatively large sample, augmented with descriptive statistics. As the research was predominantly a survey-based investigation, stratified sampling was preferred with data collecting instruments in the form of questionnaires. Analysis of variance (ANOVA) was considered in data analysis, complemented by a few other data analysis techniques to enhance the quality of the results.

\section{Background}

Whilst Zimbabwe's economic regression that reached its peak in 2008 may be contextualised within the global economic crisis, it is important to note that Zimbabwe's economy had begun a downward spiral almost a decade earlier. Zimbabwe witnessed an incomparably dire socio-economic downturn, especially between 2003 and 2008. During this time, the record hyperinflation peaked at 231 million per cent (in July 2008) (RBZ Monetary Policy 2008), but the Cato Institute of Calculations and Forbes Asia put the figure at above 500 million per cent, year on year. The variance can be explained by the fact that the Reserve Bank of Zimbabwe may have felt duty-bound to self-censor and obliged to publish conservative figures of inflation to allay simmering public discomfort at the rate at which the economy was degenerating, whilst external institutions located far from reality could have obtained skewed data, but could also have felt the need for more objectivity. Whatever the true reflection of the inflation figures, the reality was that Zimbabwe had degenerated into a state of hyperinflation that virtually brought the economy to its knees, and companies were faced with the need to survive yet still realise growth within global capitalism.

The financial services sector, especially the insurance industry (which consisted of 83 companies), was severely affected. These sectors, according to the then Governor of the Reserve Bank of Zimbabwe, Dr Gideon Gono, are 'driven by public confidence' (November 2012). Contextually, public confidence waned as the inflation set in. In the said Zimbabwean scenario, the question arose of whether some insurance companies' ability to emerge out of the hyperinflationary environment to stabilise and align with the new growth trajectory was attributable to certain aspects of EO and, in particular, the extent to which they would take risks and the risk attributed to tolerating failure.

Table 1 shows the distributions of the insurance companies in the insurance industry in Zimbabwe by class posthyperinflation.

Whilst most of the 83 insurance companies survived the hyperinflation trauma, a few became casualties and others had to reopen post-hyperinflation period.

This consequently meant that during the hyperinflation, corporateleaders were forced to intensify their entrepreneurial prowess in pursuit of economic stability within their organisations, and reinvigorate their companies' ability to withstand the treacherous business environment through undertaking deliberate, strategic and vibrant entrepreneurial activities. It is worth noting that many companies that collapsed or lagged behind in entrepreneurship and innovation could have been so because of their failure to tolerate failure, always wanting the best from their employees everyday and leaving no room to experiment and try out new methods much needed in the unfolding socio-economic and political environment characterised by volatility, uncertainty, complexity and ambiguity.

Buoyed by the need to confront hyperinflationary vagaries, such as stunted growth, erosion of markets, loss of public confidence in the insurance products and international competition on the global markets, intensified entrepreneurship looked more promising as a panacea for these challenges (Kreiser, Patel \& Fiet 2013; Nie, Dowell \& Lu

TABLE 1: Number of insurance players by class.

\begin{tabular}{lc}
\hline Insurance type & Number of players \\
\hline Life assurers & 11 \\
Short-term insurers & 23 \\
Reinsurers & 11 \\
Funeral assurers & 11 \\
Brokers & 27 \\
\hline Total & $\mathbf{8 3}$ \\
\hline
\end{tabular}

Source: Insurance and Pensions Commission 2013 
2012; Reynolds et al. 2000). Ordinarily, such pursuit of entrepreneurial intensity, especially tolerance of failure, allows for organisations to be creative and innovatively adequate to protect their market territory, sustain profitability, enter into new markets and avoid becoming useless and defunct (Smith 2010). Therefore, insurance companies that needed to continue in business during and after the hyperinflationary period needed to tolerate failure and inculcate a culture of risk-taking.

\section{Research problem}

The problem in this study is that as the hyperinflation set into the economy, many insurance companies in Zimbabwe abandoned vital principles of entrepreneurship, in particular, tolerance for failure and risk-taking, which ironically could have given them the impetus to entrepreneurial intensity to survive the inflationary impairment. Others, however, could have embraced entrepreneurial intensity and, in particular, the elements of tolerance for failure and, broadly, risk-taking to navigate their enterprises through the treacherous hyperinflationary environment. Therefore, a management dilemma was whether to engage in entrepreneurship and, in particular, tolerance of risks such as failure in an environment (e.g. hyperinflation) in order to realise entrepreneurial performance. Consequently, the failure to survive could be attributed to the lack of tolerance for failure and risk averseness. This problem is looked at from the perspective of evidence gathered in the insurance industry in Zimbabwe.

\section{Research objectives}

The study is guided by the following objectives:

- to explore the extent to which tolerance for failure tends to encourage entrepreneurial performance

- to explore the extent to which risk-taking tends to encourage entrepreneurial performance.

\section{Research questions}

The following research questions were postulated to guide the study:

- Do insurance firms that tolerate failure encourage entrepreneurial performance?

- Do insurance firms that tolerate risk-taking encourage entrepreneurial performance?

\section{Hypotheses}

Hypotheses have been propounded to explain the extent to which tolerance of failure encourages entrepreneurial performance in difficult times. Entrepreneurial performance is gauged by the assumed proxies of innovation, growth and profitability:

H1: Tolerance of failure encourages entrepreneurial performance.

H2: Growing companies tolerate failure among employees.

H3: Profitable companies tolerate failure.

\section{Literature review}

This section explores the concepts of 'tolerance of failure' and 'risk-taking' and how these are critical behavioural constructs to the well-being of firms.

\section{The essence of entrepreneurship in hyperinflationary environments}

The business environment is often fraught with nuisances and economic irritations that inhibit the proper flow of the business processes and activities. Inflation is one such nuisance and is most detrimental to the business environment. An economic state of hyperinflation has always brought about socio-economic quagmires and socio-political upheavals. It usually occurs when liquidity and real wages start increasing beyond their fundamental values (Dreger \& Zhang 2011; Makinen 2017). This increase in liquidity and wages, in turn, triggers price increases, which subsequently impact wages, causing a vicious cycle. Thomsett (2011:73) buttressed by Kararach and Otieno (2016) posits that 'the real definition of inflation is the gradual erosion of purchasing power'. In the context of Zimbabwe, the local currency essentially collapsed (Nhavira \& Ocran 2014) because of the magnitude of the hyperinflation.

In situations of socio-economic unpredictability, it is difficult for businesses to function normally, unless they deliberately resort to entrepreneurial intensity to grow and realise profitability that is embedded in risk-taking proclivity, of which tolerance of failure is a critical aspect. Nikolov and Urban (2013) are of the opinion that corporate entrepreneurship becomes very important for firms that want to achieve sustainable competitive advantage in a highly competitive environment and to survive in financially constrained environments, especially where prior entrepreneurial recognition is absent.

\section{Entrepreneurial failure: Predicting entrepreneurial success}

The term 'failure' always bears a negative connotation. However, failure can affect an entrepreneur either negatively or positively. Negatively, failure leads to stigmatisation and low esteem of the entrepreneurs and their organisations when previous efforts have not succeeded (Cardon, Stevens \& Potter 2011; Kuntze \& Matulich 2016). Positively, failure can be a learning curve to encourage entrepreneurial performance in future efforts based on human capital theory (Park, Park \& Kim 2017). Researchers and psychologists have confirmed that failure, which He (2013) calls the 'mother of success', precedes entrepreneurial success. Some scholars have even suggested that future academic inquiry should be less preoccupied with realising entrepreneurial success and circumventing failure to a re-directed and harmonious viewpoint of how success and failure are integrated (McKenzie \& Sud 2008) to enhance corporate performance. Roux and Pretorius (2017) suggest that entrepreneurs should often heed Winston Churchill's advice to learn from history when he famously said, those who fail to learn from history 
are doomed to repeat it. Similarly, if entrepreneurs learn from their failures, they are better for not repeating the same mistakes that would lead to venture failure once more.

The term 'failure' has different meanings for different situations, but a common meaning is the inability to get things right as previously expected. Whilst the Oxford English Dictionary defines 'failure' as 'to become deficient, to be inadequate', Zahra (2010) sees failure as an inability to do something right as expected, and in the case of the business, performing poorly. It is an acute deviation from the desired state of things. This is echoed by He (2013) who says failure is apparent when a performance is below expected levels. Key to the above definitions is the presence of a strong vision vital for the entrepreneurs to determine the meaning and extent of failure (McKenzie \& Sud 2008).

Entrepreneurship is littered with many obstacles and as such incidents of failure become inevitable. It is difficult to discuss entrepreneurship without appreciating the role of failure in the success story of most entrepreneurs and entrepreneurial ventures. Research suggests that entrepreneurship is not indisputably bad, but instead affords entrepreneurs and firms to learn from their failure and thus improve on their chances of ultimate success (McKenzie \& Sud 2008). Consequently, some scholars have resorted to developing some dynamic learning viewpoints of entrepreneurship to understand how failure leads to entrepreneurial performance (He 2013; Wei \& Hisrich 2017), even in detrimental environments such as the hyperinflation.

\section{Entrepreneurial behaviour and performance}

It remains a puzzle as to how certain entrepreneurial behaviours spring into action in constrained environments 'in which each piece is fitted into the place selected for it by the concatenation of pertinent circumstances' (Baumol 2010). However, what is true is that a firm's profitability derives from certain levels of entrepreneurial behaviour, which, in turn, depends on the level of organisational creativity (Bratnicka, Gabrys \& Bratnicki 2013). Risk-taking and tolerance for failure are critical elements of that behaviour which resides in human capital. It is the human capital that is often seen as guiding entrepreneurial behaviour and is critical in facilitating entrepreneurship as well as enhancing performance (Farrukh, Ying \& Mansori 2015; Zarutskie 2010). The reason why some but not all people engage in entrepreneurial behaviour (Shane \& Vankataraman 2000) is that people respond differently to entrepreneurial opportunities and subsequent entrepreneurial decisions, such as when and how to take risks and tolerate failure. According to Kuratko et al. (2005) and Gusman and Febrian (2016), middle-level managers' entrepreneurial behaviour is linked with successful corporate entrepreneurship, given the context that the role of top-level managers revolves around the making of effective strategic decisions such as risk-taking and inclination towards tolerating failure. Consequences of entrepreneurial behaviour, such as tolerance to failure, should ultimately be rewarded if the entrepreneurial performance culture is to be upheld and sustained. Such rewards are often expressed through profitability and growth (Johannesson \& Jorgensen 2017; Nieman \& Niewenhuizen 2009; Trang 2018).

Thus, performance becomes critical in entrepreneurial behaviour of risk-taking and tolerance for failure. Explaining entrepreneurial performance has long remained a contentious issue as efforts to arrive at an explanation and theory of what determines its threshold have not been able to produce desired and unanimously accepted results (Phan 2004; Shane \& Venkataraman 2000 in Kumar 2007:55). In essence, scholars recognise that whilst entrepreneurship is a 'must practice' for organisations that wish to do better, determining the extent of its success may not be easy and cannot be generalised across industries.

Entrepreneurial performance usually occurs on both the individual and organisational levels. It is essential that through the available measuring instruments, an organisation should gauge the performance levels of its employees and, ultimately, itself. The measurement of entrepreneurial performance should be against the costs sunk into the enterprise to realise not only increased revenues but also profitability and growth, and sinking such costs can be risky. Figure 1 depicts critical variables for entrepreneurial performance.

It is apparent from the above discussion that failure tolerance, an aspect of EO of organisational leaders, remains fundamental to catalyse intensified entrepreneurship. Both internal and external variables are leveraged to realise the expected outcomes and consequences, such as improved export receipts, profitability and growth.

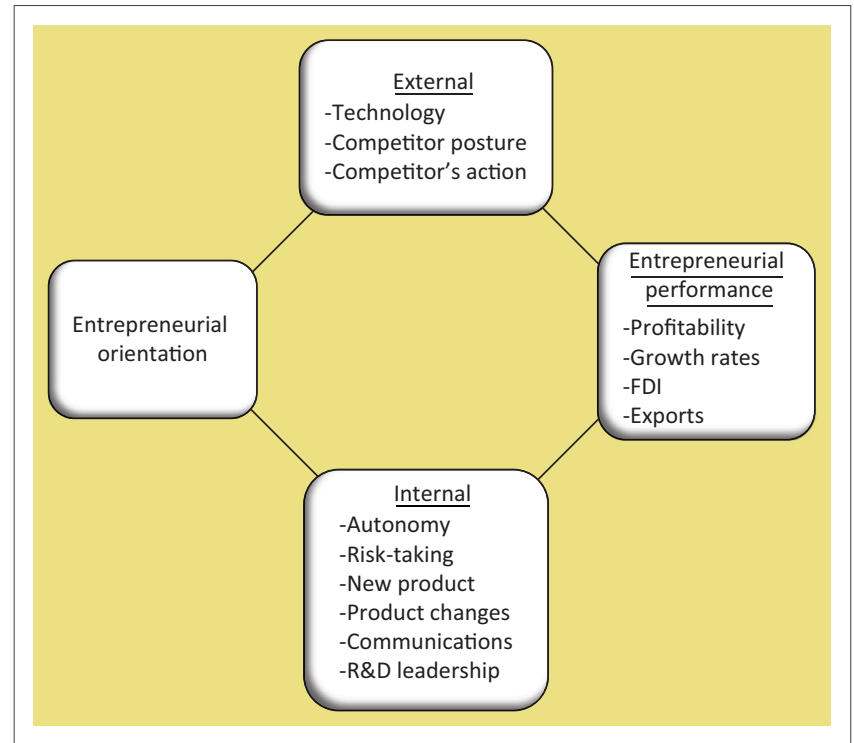

FDI, foreign direct investments.

Source: Gowrishankar, K., 2008, 'Insights into entrepreneurial behaviour in Indian firms', Academy of Entrepreneurship Journal 14(1), 95-105

FIGURE 1: Entrepreneurial performance. 


\section{Key dimensions for firm performance}

Relating from dimensions of EO essential to how the organisation eventually performs, Morris et al. (1996:6; De Jong et al. 2015; Hinz 2017) buttressed by Trang (2018) discuss three key dimensions underlying behaviours and attitudes of entrepreneurs: founding or managing ventures such as innovativeness, proactive behaviour and risktaking propensity. These key dimensions are important to understand how entrepreneurial firms can perform depending on the nature of their undertakings and the extent thereof.

\section{Proclivity for risk-taking}

One of the critical dimensions of a deliberate pursuit of entrepreneurial performance is the leadership's readiness to take risks in pursuit of opportunities that may not have existed previously. The propensity for risk has constantly been associated with entrepreneurs.

Cox and Jennings (1995) and Ojewumi et al. (2018) consider that successful entrepreneurs usually take calculated risks. According to Josien (2012:21), risk-taking as a concept is more relevant today than it was in the Cantillonic era. Richard Cantillon (1680-1734) in Brewer (2002) used the construct 'risk-taking' to differentiate a hired employee of a firm from the founder and owner, with the latter bearing the consequences of risks and uncertainty involved in a venture.

Risk-taking is defined as the willingness by the entrepreneur to deploy significant resources in a venture which has reasonable chances of failing (Ali \& Wajid 2012:1; Ferguson, Dougherty \& Nuebert 2014; Morris et al. 1996:6). Dess, Lumpkin and Eisner (2010:456) add that risks involve certain executive decisions in favour of a specific strategic course of action, thereby steering the company in a particular direction with significant implications for executives' careers. Hence, the entrepreneur attempts to ensure that the risks are calculated and manageable. Usually, risk is taken without due consideration of probable consequences. This may include deploying certain levels of resources without the applicable knowledge of, for instance, whether the results of the actions will be favourable or not. Generally, it is a strategy to resort to risk-taking in chaotic situations in order to get by and mitigate the effects of such situations.

Mobilisation and deployment of resources into areas of uncertainty, such as exploration of new markets, launching new products or undertaking a new venture, are all endeavours strewn with risks that corporate entrepreneurs must concern themselves with, either to reduce or to eliminate them, but with potentially high rewards. Only when corporate leadership is keen on entrepreneurship would their firm enter such risky business areas. In so doing, profit remains the reward for an entrepreneur taking risks and dealing with uncertainty (Knight 1921).
Most companies that have survived similar situations might have been able to do so by deliberately taking a measured risk and balancing that with the potential benefits to be accrued in the process. Figure 2 illustrates a proposed relationship between risk-taking and the performance of a firm.

The diagram in Figure 2 illustrates that as the corporate entrepreneurs take risks, the chances of the company with respect to mitigating the environmental challenges grow and the performance of the company correspondingly alters. However, the risks need to be prudently applied, mitigated, measured and calculated so that they are not carelessly and randomly taken without proper analysis of the possible implications. As shown in Figure 2, as the risk becomes too high, the performance of the company starts deteriorating. Some losses become inevitable, especially in a distressed economy.

\section{Measuring entrepreneurial performance}

Growth, profitability and innovation are contextually assumed to be proxies of entrepreneurial performance in the firm.

\section{Innovativeness}

Innovativeness refers to willingness to support creativity and experimentation in introducing new products and services, and novelty, technological leadership as well as research and development (R\&D) in developing new processes (Lumpkin, Cogliser \& Schneider 2009). The degree and the numbers of innovations as well as the high rate of technological products and processes affirm the entrepreneurial performance of the firm. Innovative companies by creating and introducing new products and technologies can generate extraordinary economic performance and have even been deemed the engines of economic growth (Croitoru 2008; Li, Huang \& Tsai 2009).

\section{Growth}

Growth is often used as a proxy for business performance and remains an ultimate measure of entrepreneurial excellence; as a result, growth as a measure of performance may be more accurate and accessible than accounting measures of financial

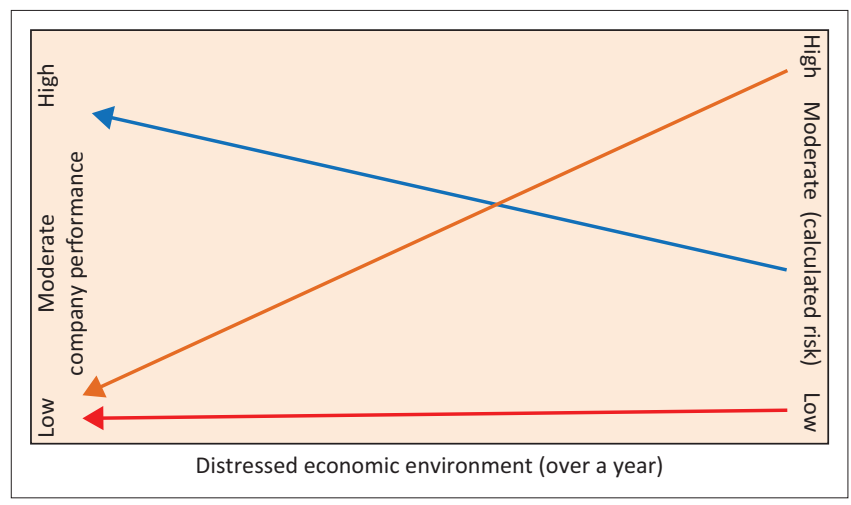

Source: Eccles, R.G. \& Serafeim, G., 2013, 'The performance frontier', Harvard Business Review 91(5), 50-60

FIGURE 2: A proposed risk-performance symbiosis. 
performance (Wiklund \& Shepherd 2005). The growth factor is always both a motive and a consequence for any businesses whether small or large. Hisrich, Peters and Shepherd (2008:45) consider that every entrepreneurially managed firm has the desire to rapidly grow the organisation.

There can be little doubt therefore that the predominant view embodied in the entrepreneurship literature is that entrepreneurial leadership and teams exist and are disproportionately involved in the establishment of ventures that have the potential for rapid growth and expansion of the firm (Carland \& Carland 2012). In fact, the many attempts at defining entrepreneurship would view the entrepreneur as someone who, in the process of building a vision, establishes a business aiming for profit and growth (Inacio \& Gimenez 2012:42; Nieman \& Niewenhuizen 2009:9). This means that the firm's growth aspiration is at the heart of entrepreneurial activities.

\section{Financial performance and profitability}

Entrepreneurship performance can best be measured by wealth creation prowess and profitability (Classen et al. 2012). Turnover numbers will therefore help indicate the rate of human activity in the firm in wealth creation efforts. Financial or other tangible rewards that are made possible by the firm's financial performance are examples of extrinsic entrepreneurial outcomes (Kuratko et al. 2005). Demographic data often point to and determine the firm's performance as determined by both external and internal independent variables, which is directly related to the financial performance of the firm given by the dependent variables: growth rate, profitability, per cent earnings from export and foreign direct investments (Gowrishankar 2008).

Profitability therefore remains an objective not simply of setting up the venture, but also of acting entrepreneurially in an established corporation. Nonetheless, the motivation for a profitability-embedded organisational performance is more desirable but very difficult to attain in a business environment of economic uncertainty.

\section{Corporate entrepreneurship}

Kuratko, Hornsby and Goldsby (2007:56) and De Jong et al. (2015) opine that corporate entrepreneurship is being embraced by many organisations as not simply a component of a company's strategy, but rather as the very framework for the company's future critical success imperatives and activities. Farrukh et al. (2015) concur that corporate entrepreneurship is the legitimate route available to realise increased levels of entrepreneurial performance.

Corporate entrepreneurship attempts to locate entrepreneurship in the context of a firm. As such, entrepreneurial activities and behaviours in larger, established organisations have been termed as corporate entrepreneurship (Clohessy, Holt \& Rutherford 2007). According to Ireland, Kuratko and Morris (2006), corporate entrepreneurship allows individuals within a firm to explore and exploit opportunities and innovate notwithstanding the availability of resources.

Sathe (2003:2) adds that corporate entrepreneurships are efforts by corporations to generate new business and counter an array of challenges in the business environment, such as market stagnation and bureaucracy (Serai, Johl \& Marimuthu 2017; Todorovic, Todorovich \& Ma 2015). Unstable business environments in recent years have witnessed corporations moving towards deliberate efforts at corporate entrepreneurship practices with those companies that fail to reinvent themselves within the context of entrepreneurship dying. Broadly, corporate entrepreneurship is defined as the development of business ideas and exploration of opportunities in the context of an established firm (Birkinshaw 2003; Birkinshaw, Hood \& Young 2005; Kang 2014; Kuratko \& Hodgetts 2004; Russo 2010; Trang 2018). Some of those opportunity exploratory efforts can be futile and risky, leading to failure.

Corporate entrepreneurship has for a long time been recognised as a potentially viable means for promoting and sustaining organisational performance, business renewal and corporate competitiveness. The entrepreneurial activities help companies to develop new businesses that create new revenue streams. In its broader definition, corporate entrepreneurship therefore embodies risk-taking, proactiveness and radical product innovations. These corporate entrepreneurship activities can improve organisational growth and profitability and, depending on the company's competitive environment, their impact may increase over time. The empirical evidence is compelling that corporate entrepreneurship improves company performance by increasing the firm's proactiveness and willingness to take risks, and by pioneering the development of new products, process and services through enriching its competitiveness.

It therefore becomes imperative that those people in strategic positions within an organisation are able to exhibit entrepreneurial inclination and attitudes needed to drive entrepreneurship within the company (Dess et al. 2010).

\section{Entrepreneurial orientation}

Entrepreneurial orientation refers to a firm's strategic alignment, capturing specific entrepreneurial aspects of decision-making styles, methods and practices, and as such, it reflects how a firm operates rather than what it does (Ayodotun et al. 2018; Wicklund \& Shepherd 2005:74). According to Dess et al. (2010), EO refers to the entrepreneurial strategies that business organisations employ to explore and start up new ventures. Entrepreneurial orientation, when measured at the individual level, is related to categorical directionality and describes the propensity for someone to lead a new venture (Liao, Murphy \& Welsch 2005). Doing so would require propensity for risk and tolerance for failure. 
Dess and Lumpkin (2001:431) have advanced five critical dimensions of EO, which include autonomy, innovativeness, risk-taking, proactiveness and competitive aggressiveness (Gupta, Chen \& Gupta 2016). Risk-taking would therefore mean a tendency to take bold decisions such as venturing into unknown new markets, committing a large portion of resources to ventures with uncertain outcomes and/or borrowing heavily with a chance to fail.

It is therefore evident that EO-performance relationship is well established (Johannesson \& Jorgensen 2017) in firms. It should be well established and vibrant in the insurance industry as well, even in the largely uncertain economic environment that Zimbabwe has been for much of its postindependence era. Seemingly, there is justification by scholars in focusing on and emphasising the individual entrepreneur orientation because it is the individual who drives the firm, hence the importance advanced by businesses in facilitating the identification of the right calibre of corporate entrepreneurs with appropriate motivation and skills set including propensity for risk-taking and tolerance to failure to assist in the running of the enterprise.

\section{Tolerance of failure: An antecedent of performance}

Regardless of how the enterprises are started, what influences their need to start up, and ultimately every decision thereafter, entrepreneurs might fail, just like Donald Trump who started with US\$1 million from his father but still failed before rising again; they all learn from failure (Liang \& Dunn 2014). It means that at one point or the other in the entrepreneurial journey, failure is an inevitable reality an entrepreneur must be prepared for but must choose whether to learn something from the failure and start again, be more determined or to resign altogether. Tolerance of failure is therefore a critical aspect of risk proclivity and is considered a key antecedent of corporate entrepreneurship and the overall desired organisational performance. In fact, tolerating failure is a risk in itself, a luxury many managers are not willing to take as their shareholders are impatient for want of quick returns on investment. Kuratko, Montagno and Hornsby (1990) stated that tolerance of failure is a worthy antecedent of corporate performance. This notion is echoed by Jennings and Lumpkin (1989) and others (Havlíček, Thalassinos \& Berezkinova 2013; Wood et al. 2008). Therefore, managers are encouraged to recognise and create an environment that encourages risk-taking whilst maintaining reasonable tolerance for failure (Hornsby, Kuratko \& Zahra 2002) as this guarantees sustainable organic growth of the enterprise and profitability.

Variously, scholars seem to confirm that for the insurance industry in Zimbabwe to have survived the hyperinflation environment, there was some measure of tolerance to failure as failure was inevitable and aggravated by the fact that not many managers had prior experience of managing firms in such an environment before. Equally, there could have been major risks taken in an environment of uncertainty for the firms to keep their heads above the water.
Risk-taking and tolerance of failure are said to often appear frequently in entrepreneurship literature as critical variables for fostering entrepreneurial activity. It suffices to conclude therefore that just like risk-taking, tolerance of failure is a critical component of entrepreneurial behaviour and an important antecedent of entrepreneurial innovation and success. When employers are willing to allow the employees to make mistakes, they are doing so as a calculated risk (Kilenthong \& Hultman 2016), which leads to the belief that through making mistakes they are in fact learning to do things right and better. At worst, organisations realise losses, sometimes invest in products that fail to penetrate the market and face rejection, and ventures may even face extinction and collapse.

Organisations that tolerate failure believe that failure is an inevitable but critical aspect of success and should therefore not only be tolerated but also be encouraged and supported (Urban \& Gaffurini 2017). Chirani, Farahbod and Pourvahedi (2013) have gone further to remark that tolerance of failure ranks among other critical entrepreneurial characteristics of self-confidence, self-reliance, perseverance and commitment for ensuring success.

\section{Cultural barrier to entrepreneurial innovations and performance}

Culture has not made it easy to spur innovations and, ultimately, entrepreneurial performance. It is noted that cultural diversity has a tendency to suppress creativity and entrepreneurial innovations (Mir-Babayev et al. 2017), and ultimately firm performance. The African cultural environment, for instance, has certain barriers negating entrepreneurship, innovations and creativity, with constant reference to social hierarchy that inhibits entrepreneurial performance (Conger \& Kanungo 1994; Erickson \& Laing 2016; Nieman \& Niewenhuizen 2009:12; Welsch 2003:147). The belief is that certain people in society should not be let to their whims and decisions freely as they may not be expected by society to do anything right and worthwhile let alone entrepreneurial activities. Such low expectations of other members of the society tend to encourage intolerance of failure and risk averseness. When such failure happens, society is ready to criminalise and punish offenders to the extent that they will not be ready to take risks in the future, thereby negating entrepreneurial intensity. The same applies to the caste system in Indian society, for instance, which has created over centuries a hierarchical system that has exhibited low tolerance of failure largely because of their observation of upward hierarchical progression (Bansal 2011).

\section{Entrepreneurial failure: Performance nexus}

Whilst some scholars remain sceptical about the link between entrepreneurial rewards from entrepreneurial failure owing to the lack of availability of strong evidence linking entrepreneurial failure to actual benefits of the initial loss (Luzzi \& Sasson 2016; McKenzie \& Sud 2008), according to McKenzie and Sud (2008), other scholars have since agreed that there are benefits to be realised from learning from 
failure. Even as tolerance of failure is seen as a risk, when it is well calculated like any risk, it tends to reward the entrepreneurs and their enterprises. However, before such benefits have been realised, entrepreneurs must have learnt to cope with failure they would have gone through. Whilst failure could affect the ability to learn critical lessons from the incidents, Shepherd (2003) has proposed that failure arising from entrepreneurial strategic decision-making, if well managed, can become a relevant learning curve and an important source of wisdom and entrepreneurial education for entrepreneurs (Kuntze \& Matulich 2016; Nouri et al. 2018), especially as they may want to embark on a business rescue mission (le Roux \& Pretorius 2017), where learning from the failure would prove worthwhile. Other scholars such as Cannon and Edmondson (2005) have noted that benefits of failure are more in providing counselling and encouragement than they are in pragmatic situations; it is therefore important to comprehend the environment and circumstances in which failure has occurred in order to make the best out of the situation. Thus, it is important to understand how the entrepreneurs and their ventures would have failure in order to learn from the failure, as according to Liao, Kickul and Ma (2009), critical stakeholders, such as entrepreneurs themselves, financiers, policy thinkers and even management and boards and shareholder proxies, need critical information about how failure would have occurred to understand and learn from it going forward.

There is empirical evidence from contemporary entrepreneurship literature that suggests that failures are actually vital engines that trigger change for the better (Chuang \& Baum 2003 cited in He 2013; Kim \& Miner 2007) if the story of Steve Jobs and many other successful entrepreneurs is anything to go by. Going by the initial failures that met entrepreneurs such as Donald Trump and Steve Jobs, they are lessons that failure can provide. According to Hopkins, Hopkins and Thornton (2002:14), research has shown that companies operating in high-tech environments tend to exhibit high levels of tolerance of failure and their employees also exhibit willingness to take risks and independent action, leading to the promotion of entrepreneurial performance within the firm (Tse \& Euchner 2017). He (2013) provides some of the critical questions on failure:

$[H]$ ow do entrepreneurs develop leadership skills in the process of making mistakes, failing, and learning from their mistakes and failure? Why do some entrepreneurs learn from this experience and become better leaders, while others do not? (p. 2)

Entrepreneurial thinking is a critical element of creativity that allows even big firms to compete and succeed against other giants (Montiel-Campos 2018; Prosek 2011). Effective planning and problem solving in a rapidly changing global business environment call for entrepreneurial thinkers who can go beyond merely logical or linear cognitive orientation of rules, reason, rational logic and scientific cause-effect predictability to also include thought patterns of intuitive and emotional assessments, creativity and lateral thinking and total systems appraisal, integrative and synergetic thinking, perceptual flexibility, imagination and visualisation (Vance et al. 2012) with much risks. Therefore, tolerance for failure is a critical aspect of entrepreneurship with potential to ignite creativity and thinking in the same breath as other paradigms of the broader entrepreneurial culture, such as opportunity seeking, complexity, uncertain environments and market competition (Knosková 2015). Lubatkin and Chatterjee (1994) say that failure is a built-in component of entrepreneurship, given the amount of uncertainties and risks involved in entrepreneurial activities. Therefore, it is highly probable that failure can lead to entrepreneurial innovations if well handled, and ultimately to greater performance.

Challenges and failures spur those who experience them to start thinking beyond their capabilities in pursuit of solutions to such failures. They become innovative. Problems such as those presented by the hyperinflation in the insurance industry would have encouraged company management and leaders to start thinking about solutions beyond what they would ordinarily have conceived. When premiums were no longer coming in, and when insurance companies could no longer pay out policyholders and meet their obligations, it became a big challenge to create new ideas to solve the prevailing problems.

According to Aldrich and Fiol (1994) cited in (He 2013), for some time now scholars in entrepreneurship have been seized with research that is moving from success orientation and tendency to avoid failure to finding how both phenomena could be integrated for higher performance. Therefore, management should show willingness to obligate significant resources to seek out opportunities that have both a chance of failure and the opportunity for success (Wang et al. 2015).

\section{Resourcing entrepreneurial failure}

As mentioned by Urban and Gaffurini (2017), proactive managers should not only encourage but also support their mantra for tolerance for failure by putting aside resources such as time, money and equipment. More often, it might be viewed that time and money are expended at resourcing what could be deemed as vain efforts. Evidently, a budget put up for R\&D is an example of resourcing tolerance for failure and risky decisions, as not all research outcomes can be useful, durable or timely and relevant to current opportunities and needs. But entrepreneurially speaking, the efforts are not in vain as failure, if strategically capitalised and managed, is often the beginning of sustainable success. This argument is buttressed by the resource-based theory.

According to Alverez and Busenitz (2001), resource-based theory articulates that mobilisation of critical resources becomes imperative to create sustainable competitive advantage for the enterprise as resources are associated with unique capabilities that the organisation would need, 
especially in difficult environments (Agwu 2018; Sar 2017; Sibanyoni \& Mupambwa 2017). It follows therefore that management that is able to prioritise resource mobilisation and apply such resources most effectively will also be the ones that are likely to enjoy superior entrepreneurial performance (Coleman \& Robb 2010). Such resources may be utilised in R\&D and other innovative products and processes, some of which will not see the light of day. According to Gillis, Combs and Ketchen (2014), resource-based theory describes the characteristics of strategic assets, which are resources and capabilities that spawn performance differences among firms. Sirmon, Hitt and Ireland (2004; 2007), however, add that these resources need to be appropriately deployed to elicit the relevant competitive advantage for the enterprise.

It is for this reason that this study is influenced by resourcebased theory, understanding the importance of resources to influence and leverage entrepreneurial performance. More importantly, this theory becomes relevant in advancing the concept of entrepreneurial intensity driven by a sound relationship between resources and gaining a competitive advantage in the marketplace as well as making the best potential of costs opportunism and realisation of strategic business outputs.

The attracting, mobilising and deployment of resources are, therefore, critical to the entrepreneurial process, and consequently the entrepreneurial intensity. An intention to embark the organisation on intensified entrepreneurship is neither an accident nor an afterthought, and although the exploitation of the opportunity is central to their thinking, entrepreneurs are still concerned with committing certain levels of resources into the enterprise (Hisrich et al. 2008), albeit calculatedly for fear of failure. Capelleras et al. (2010) postulate that to examine the variety of factors influencing entrepreneurial outcomes, such as venture creation speed, it is necessary to take into account not only internal resources of the firm but also individual perceptions about environmental resources.

Whilst failure could be inevitable in most circumstances, entrepreneurship must essentially be fully resourced to ascend into the desired plane of performance. Resourcebased theories of firm strategy, such as resource-based view (RBV), suggest that firms with valuable, rare and inimitable resources have the potential to achieve superior performance (Raffo, Clark \& Arik 2016; Wiklund \& Sherphard 2003:1307). According to Shokri (2012), these resources include capital (investments in businesses), participation, knowledge and skills of workers, physical equipment and buildings. Attraction and use of capital is one of the key tasks of an entrepreneur to gather necessary resources and innovate competitively to become profitable. Lichtenstein and Brush (2001:40) observe that in the early stages of firm growth, resources are key and being able to ascertain and procure these resources becomes crucial if entrepreneurial firms are to survive and prosper (Jones \& Jayawarna 2010:129), especially in distressed economic situations such as the decade-long hyperinflation that Zimbabwe went through. However, in so doing, it must be observed that success is not imminent and might be intercepted by failure before it is achieved.

\section{Research methodology and design}

A research design is defined as a blueprint that expresses both the structure of the research problem and the plan of investigation to obtain empirical evidence (Blumberg, Cooper \& Schindler 2008:195; Collis \& Hussey 2013; Løkke \& Sørensen 2014; Wagner, Kawulich \& Garner 2012). This study is largely embedded in the positivist philosophy, making predominant use of quantitative research design augmented with descriptive statistics. The enquiry focuses on determining the general trends and opinions of defined populations. The population of interest is defined as the insurance industry in Zimbabwe. Representation of that insurance industry population is sampled. The research then generalises the findings obtained to the larger population (the insurance industry) using statistical techniques to determine the likelihood of sample findings applying to the whole insurance industry.

As a result, a cross-sectional, sequential descripto-explanatory survey research design (Pickett, Reilly \& McIntyre 2005) was opted for in this study as the researcher was in a position to take a snapshot study of the goings-on in the insurance industry in Zimbabwe during the hyperinflationary period.

The survey research design assisted the researcher to engage the large insurance industry population by surveying a sample of that population in a fast and economical manner (Saunders, Philip \& Thornhill 2009; Stockman 2015; Wahyuni 2012). A sequential descripto-explanatory survey design with its unique elements of both descriptive and explanatory research designs applied in sequence (Israel 2007; Smith 2018; Trujillo 2010) bolstered the study. Consequently, the descriptive statistics sought to describe the 'how' and 'why 'questions (Singh et al. 2012) of what happened in the insurance firms during the hyperinflationary environment with regard to tolerance for failure and risktaking, providing near-accurate profile of events and their pragmatic contexts. This was important in providing a clear and comprehensive understanding of the context in which entrepreneurship was practised, and in particular how the principles of risk-taking and tolerance for failure were dealt with. Leedy and Ormrod (2005) suggest that descriptive research is more important for understanding relationships and behaviours (Chong \& Yeo 2015; Ellis \& Levy 2009). Whatever happened would need to be explained by the explanatory design in pursuit of establishing not only what happened but also how it happened and why it happened (Saunders et al. 2009).

Consequently, the study would assume an inductive approach as the reasoning starts with an assumption of what could have happened to the insurance firms during the hyperinflation period, which after collecting and analysing data can then be generalised to the rest of the insurance industry during the same period. Therefore, the strategy was 
implanted for its descriptive ability to identify how insurance businesses survived the hyperinflation environment and how tolerance of failure and risk-taking was critical to the survival and possibly impacting profitability.

\section{Sampling and sample size}

Stratified sampling was used to increase statistical efficiency, to provide enough data for analysing various strata and to enable use of other research methods in other subgroups (Blumberg et al. 2008; Lee 2015). As the study deals with the entrepreneurial behaviours of the firm, a cross-sectional research was deemed appropriate to reach out to salaried employees, including those in management to elicit their opinions on the state of entrepreneurship in their respective organisations, especially on how the principles of tolerance for failure and risk-taking were crucial in the survival of the insurance firms during the hyperinflation period. These respondents were drawn out from a random selection of elements from various subgroups making up the insurance industry in Zimbabwe, such as life assurance, short-term insurance, reinsurance, funeral assurance and broker firms.

A sample of 307 respondents consisting of both employees and managers was deemed an adequate representation of the insurance industry in Zimbabwe.

\section{Data collection}

Surveys sought to systematically collect a body of quantifiable data with respect to a number of variables, which were then examined to discern patterns of association.

Questionnaires randomly distributed via Google forms were used to collect primary data from employees and managers working in various insurance firms in Zimbabwe. The questionnaires schedule had sets of questions, each derived from the research questions. The questionnaires were then administered to the respondents. Predominantly, the questionnaire sought to measure corporateentrepreneurial behaviour with respect to proclivity for risk-taking and innovation, both of which are proxies of tolerance for failure. The questions were therefore categorised to focus on research questions and to address the entire conceptual framework. Questions were also created to stimulate responses that sought to create an association between behavioural constructs and entrepreneurial performance such as profitability and growth.

Data analysis was performed through various statistical techniques deemed relevant and adequate for the kind of data extracted. For comparison of dichotomous groups, independent samples $t$-test was used, where data were on a ratio scale; otherwise where data were collected on an ordinal scale, an independent sample's Mann-Whitney $U$ test became more useful. However, for more than two levels of independent variables, an ANOVA sufficed, especially where the scores on the independent variable were in ratio or interval scale.

\section{Research results and discussion Instrument reliability and validity}

The question of whether the methods employed to gather data can still yield the same results at a different time and space explains reliability and validity (Wagner et al. 2012). Whilst reliability is concerned with the ability to measure the construct the same way over and over again in similar situations, validity presumes reliability. Validity is concerned with whether the measure really measures the construct it is expected to measure. Entrepreneurial performance measures were therefore advanced as growth, profitability and innovations.

To ensure reliability, the consistency of measurement internally and across time becomes critical. This article used three main variables: tolerance of failure, innovation and performance. Tolerance of failure score was computed from four constructs on risk orientation: bold action regardless of consequences, deliberate risk, elimination or minimisation of obstacles, and presence of risk governance framework. Innovation was computed from four constructs on innovation and creativity: encouragement of ideas and solutions, recognition or appreciation of innovation activities, evidence of innovative thinking in meetings, and tolerance of failure on new things, ways and processes. Scores for tolerance of failure as well as innovation were collected using a (reverse) fivepoint Likert scale (strongly agree [1], agree [2], unsure [3], disagree [4] and strongly disagree [5]) for each of the constructs. Therefore, the higher the number, the lower the level of risk orientation or tolerance of failure, as well as the level of innovation. Lastly, performance was measured using two constructs, namely, growth and profitability, all collected using an ordinal scale: growth had three categories (growth into top 2, stabilisation and deterioration out of the top 2) and profitability also had three categories (profit, breakeven and loss position). Reliability statistics were then run for these three variables (see Table 2). Internal consistency for the dimensions of tolerance of failure was generally acceptable (Cronbach's alpha $=0.74$ ), with an average of 0.57 inter-item correlation. Internal consistency for the dimensions of innovation was generally weak (Cronbach's alpha $=0.63$ ), with an average of 0.48 inter-item correlation. Lastly, internal consistency for the dimensions of performance was generally poor (Cronbach's alpha $=0.51$, with an inter-item correlation of 0.34. It could be fortuitous that the dimensions on performance had less consistency, given that they were measuring different dimensions of performance (growth and profitability).

\section{Research hypotheses}

\section{Hypothesis 1: Tolerance of failure encourages entrepreneurial innovations}

This study hypothesises that tolerance of failure ultimately results in a spike in entrepreneurial firm innovations. To test this hypothesis, entrepreneurial innovation was derived from the ability of the insurance firm to exhibit 


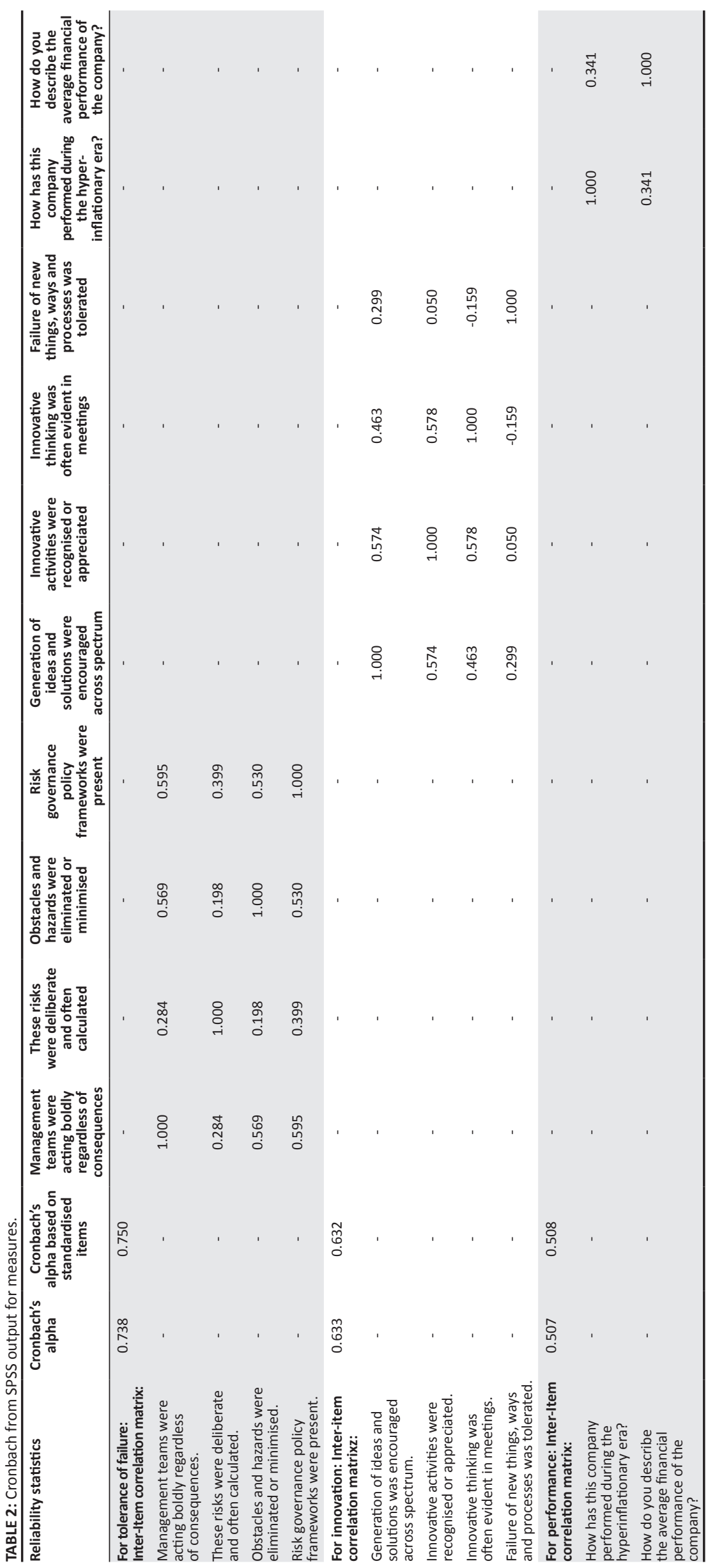


innovation and creativity, a critical dimension of entrepreneurial performance. This dimension sought to understand how various departments (financial, support services, operations, marketing and business development, and underwriting department) within the firm were entrepreneurially oriented. Therefore, the innovation and creativity dimension contained five sub-items (financial department, support services departments, operations, marketing and business development, and underwriting department) measured on a three-point scale (yes $=2$; unsure $=1$; no $=0$ ). A mean innovative and creativity score was computed and dichotomous mean comparison was performed to compare those who (strongly) agreed and those who (strongly) disagreed that tolerance of failure was present. The comparison was calculated using the independent samples $t$-test. For the purposes of this test, the response of 'unsure' on the dimensions of the presence of tolerance of failure was suppressed so that the comparison was carried out on two ends of the continuum. Agree and strongly agree were combined; similarly, disagree and strongly disagree were combined to form the independent variable to which exhibition of innovation and creativity was a dependent variable. It is important to note that this construct was measured on a three-point scale (yes $=2$; unsure $=1$; no $=0$ ); therefore, the higher the number, the higher the level of innovation and creativity. It was revealed that those who (strongly) agreed that tolerance of failure was present significantly reported exhibition of more innovation and creativity $\left(M_{2}=1.35 ; s_{2}\right.$ $=0.70)$ than those who (strongly) disagreed $\left(M_{1}=0.92 ; s_{2}=\right.$ 0.70) $(t(257)=-4.540, p=0.000)$. Therefore, the null hypothesis is rejected and it is concluded that insurance companies that have tolerance of failure encourage entrepreneurial innovations, and entrepreneurial performance in general.

\section{Hypothesis 2: Growing companies tolerate failure among employees}

The study also hypothesised that growing companies have a tendency to tolerate failure among their employees (see Table 3). To test this hypothesis, tolerance of failure score was computed from four constructs on risk orientation: bold action regardless of consequences, deliberate risk, elimination or minimisation of obstacles and presence of risk governance framework. At this juncture, it is important to comprehend that each of the four constructs for risk orientation was scored with a (reverse) five-point Likert scale (strongly agree [1], agree [2], unsure [3], disagree [4] and strongly disagree [5]). Therefore, the higher the number, the lower the level of risk orientation or tolerance of failure. Tolerance of failure mean comparison was calculated on the dimensions of growth using a one-way ANOVA. The results revealed that there was a statistically significant difference in mean tolerance of failure $\left(M_{\text {growth }}=2.32, S_{\text {growth }}=0.84 ; M_{\text {stabilise }}=2.66, S_{\text {stabilise }}=0.77\right.$; $M_{\text {deteriorate }}=3.23, s_{\text {deteriorate }}=1.16$ ) among the different categories of growth. $F_{\text {obt }}=10.49$ and is associated with $p=$ 0.000 ; we therefore reject $\mathrm{H}_{0}$ and conclude that at least one of the growth categories has a mean tolerance of failure significantly different from the other categories $\left(F_{o b t}(2\right.$; $304)=10.49, p=0.000, \alpha=0.05)$. It can be concluded that insurance companies that took the risk of tolerating failure had much better chances of growing than those that were risk-averse because the Tukey's HSD post-hoc tests revealed that the categories of 'growth into top 2 on the market' and 'stabilisation' were a homogenous subset ( $p=$ 0.22 ) significantly lower than the category of 'deterioration from outside top 2 on the market'. From the mean differences, it is apparent that the means for growth into the top 2 and stabilisation are significantly lower than that of deterioration from outside the top 2 on the market.

\section{Hypothesis 3: Profitable companies tolerate failure}

It had been propounded that those companies that make profits are likely to tolerate failure (see Table 4). To test this hypothesis, tolerance of failure score was used for comparison on the categories of profitability using a oneway ANOVA. The results revealed that there was a statistically significant difference in mean tolerance of failure $\left(M_{\text {profit }}=2.03, S_{\text {profit }}=0.56 ; M_{\text {even }}=2.56, S_{\text {even }}=0.73 ; M_{\text {loss }}\right.$ $=3.12, S_{\text {loss }}=1.05$ ) among the different categories of profitability. $F_{\text {obt }}=27.156$ and is associated with $p=0.000$; we therefore reject $\mathrm{H}_{0}$ and conclude that at least one of the profitability categories has a mean tolerance of failure significantly different from the other categories $\left(F_{\text {obt }}(2 ; 304)\right.$ $=27.16, p=0.000, \alpha=0.05)$. It can be concluded that companies that took risks or tolerated failure had much better chances of making profit than those that were riskaverse because the Tukey's HSD post-hoc tests revealed trichotomy homogenous subsets; the 'profit' category was a homogenous subset significantly lower than the 'breakeven' category which was also significantly lower than the 'loss position' category. From the mean tolerance of failure

TABLE 3: Tolerance for failure on innovations.

\begin{tabular}{|c|c|c|c|c|c|c|c|c|c|c|c|c|c|c|}
\hline \multirow[t]{2}{*}{ Average score } & \multirow{2}{*}{$\begin{array}{l}\text { Failure of new things, } \\
\text { ways and processes } \\
\text { was tolerated }\end{array}$} & \multirow[t]{2}{*}{$N$} & \multirow[t]{2}{*}{ Mean } & \multirow[t]{2}{*}{$\begin{array}{c}\text { Std. } \\
\text { deviation }\end{array}$} & \multirow[t]{2}{*}{$\begin{array}{l}\text { Std. error } \\
\text { mean }\end{array}$} & \multicolumn{2}{|c|}{$\begin{array}{l}\text { Levene's test for } \\
\text { equality of ... }\end{array}$} & \multicolumn{7}{|c|}{$t$-Test for equality of means } \\
\hline & & & & & & $\boldsymbol{F}$ & Sig. & $t$ & $d f$ & $\begin{array}{c}\text { Sig. } \\
\text { (2-tailed) }\end{array}$ & $\begin{array}{c}\text { Mean } \\
\text { difference }\end{array}$ & $\begin{array}{l}\text { Std. error } \\
\text { difference }\end{array}$ & \multicolumn{2}{|c|}{$\begin{array}{l}95 \% \mathrm{Cl} \text { of the } \\
\text { difference }\end{array}$} \\
\hline \multirow{3}{*}{$\begin{array}{l}\text { On exhibition of } \\
\text { innovation and } \\
\text { creativity }\end{array}$} & (Strongly) disagree & 183 & 0.9169 & 0.69669 & 0.05150 & - & - & - & - & - & - & - & - & - \\
\hline & (Strongly) agree & 76 & 1.3500 & 0.70437 & 0.08080 & - & - & - & - & - & - & - & - & - \\
\hline & Equal variances assumed & - & - & - & - & 0.020 & 0.888 & -4.540 & 257 & 0.000 & -0.43306 & 0.09538 & -0.62088 & -0.24524 \\
\hline
\end{tabular}

Std., standard; Sig., significance; $d f$, degrees of freedom; Cl, confidence interval. 
TABLE 4: Summary of analysis of variance tests on the dimensions of tolerance of failure.

\begin{tabular}{|c|c|c|c|c|}
\hline Dimension score $\left(\mathrm{H}_{0}: \mathrm{U}_{1}=\mathrm{U}_{2}=\mathrm{U}_{3}\right)$ & Hypothesis & $P$ & Tukey & Decision \\
\hline Tolerance of failure versus growth & $\begin{array}{l}\text { H3: Profitable companies tolerated failure } \\
\text { (NB: Tolerance of failure was computed from risk orientation mean) }\end{array}$ & 0.000 & $\begin{array}{l}\text { - Grew into top 2: Stabilise } \\
\text { - Deteriorated }\end{array}$ & $\begin{array}{l}\text { Reject } \mathrm{H}_{0} \text { and conclude that } \\
\text { profitable companies tolerated } \\
\text { failure more than those } \\
\text { that were risk-averse }\end{array}$ \\
\hline
\end{tabular}

TABLE 5: Summary of analysis of variance tests on the dimensions of tolerance of failure versus profitability.

\begin{tabular}{lllll}
\hline Dimension score $\left(\mathrm{H}_{0}: \mathrm{U}_{1}=\mathrm{U}_{2}=\mathrm{U}_{3}\right)$ & Hypothesis & $\boldsymbol{P}$ & Tukey \\
\hline $\begin{array}{l}\text { Tolerance of failure versus } \\
\text { profitability }\end{array}$ & $\begin{array}{l}\text { H3: Profitable companies tolerate failure } \\
\text { (NB: Tolerance of failure was computed from risk orientation mean) }\end{array}$ & $\begin{array}{l}\text { 0.000 } \\
\text { - Profit } \\
\text { Break-even } \\
\text { - Loss }\end{array}$ & $\begin{array}{l}\text { Reject } \mathrm{H}_{0} \text { and conclude that } \\
\text { profitable companies tolerate } \\
\text { failure }\end{array}$ \\
\hline
\end{tabular}

differences, it is apparent that the mean for those who made profit is significantly lower than those who broke even and those who broke even are also significantly lower than those who were in a loss position.

\section{Conclusion}

The study results point to the fact that tolerance of failure is likely to proffer more on the aspect of entrepreneurial innovations, although in reality such efforts may not affect profitability nor encourage growth more than those who do not tolerate failure (see Table 5). However, the broader and more composite aspect of risk-taking, with its numerous constructs other than tolerance for failure, tends to reflect that performance on the aspect of growth can be influenced by the extent to which an organisation embraces risk-taking. Overall, the study has revealed that generally tolerance of failure is a critical aspect of risktaking worth taking as it encourages employees to be innovative and entrepreneurial by experimenting and learning from initial instances of failure. Although the results did not show any difference in terms of growth and profitability, they in fact revealed that tolerance of failure may lead to growth and profitability in the broader context of risk orientation, as shown by the insurance companies studied. Companies would therefore perform better, especially in the aspect of innovations, by tolerating failure among their employees, albeit calculatedly as advocated by the findings and buttressed by various scholarly literatures, and give the employees the latitude necessary in driving the business to sustainable performance without fear of detrimental ramifications of their actions to the business and consequences to themselves.

\section{Acknowledgements Competing interests}

The authors declare that they have no financial or personal relationship(s) that may have inappropriately influenced them in writing this article.

\section{Authors' contribution}

O.K. conceptualised the study and developed the article, whilst Prof. J. van Vuuren edited the article. Both authors read and approved the final manuscript.

\section{References}

Agwu, E., 2018, 'Analysis of the impact of strategic management on the business performance of Smes in Nigeria', Academy of Strategic Management Journal 17(1), 1-20.

Aldrich, H.E. \& Fiol, C.M., 1994, 'Fools rush in? The institutional context of industry creation', Academy of Management Review 19(4), 645-670.

Ali, J.R. \& Wajid, S., 2012, 'Entrepreneurial and intrapreneurial orientation in Indian enterprises: An empirical study', South Asian Journal of Asian Studies 19(3), n.p.

Alvarez, S.A. \& Busenitz, L.W., 2001, 'The entrepreneurship of resource-based theory', Journal of Management 27(6), 755-775.

Arasti, Z., 2010, Perceived causes of business failure: An empirical study of Iranian entrepreneurs, Academic Conferences International Limited, Reading, vol. 9, p. 61.

Ayodotun, I.S., Oyebisi, I.M., Maxwell, O.A., Oluremi, O.A., Adebanji, A.W., Hezekiah, F.O. et al., 2018, 'Examining the moderating effect of entrepreneurs' demographic F.O. et al., 2018, 'Examining the moderating effect of entrepreneurs' demographic
characteristics on strategic entrepreneurial orientations and competitiveness of characteristics on strategic entrepreneurial orientations
SMEs', Journal of Entrepreneurship Education 21(2), 1-8.

Bansal, P.C., 2011, 'From Jugaad to systemic innovation: The challenge for India', Indian Journal of Industrial Relations 6(3), 536.

Baumol, W.J., 2010, The microtheory of innovative entrepreneurship, Princeton University Press, Princeton, NJ.

Birkinshaw, J., 2003, 'The paradox of corporate entrepreneurship', Strategy and Business, 13 February, pp. 46-57.

Birkinshaw, J., Hood, N. \& Young, S., 2005, 'Subsidiary entrepreneurship, internal and external competitive forces, and subsidiary performance', International Business Review 14, 227-248. https://doi.org/10.1016/j.ibusrev.2004.04.010

Blumberg, B., Cooper, D.R. \& Schindler, P.S., 2008, Business research methods, 2nd European edn., McGraw-Hill, New York.

Bratnicka, K., Gabrys, B. \& Bratnicki, M., 2013, 'How organizational creativity influence firm's profitability: The moderating role of corporate entrepreneurship', in European Conference of Innovation and Entrepreneurship, Brussels, Belgium, September 19-20, 2013, pp. 116-125.

Brewer, T., 2002, Richard Cantillon: Pioneer of economic theory, Routledge, London.

Burke-le Roux, A. \& Pretorius, M., 2017, 'Exploring entrepreneurial learning during formal business rescue processes: Insights from the South African experience', $S A$ Journal of Human Resource Management 15(1), 1-15. https://doi.org/10.4102/ sajhrm.v15i0.733

Cannon, M.D. \& Edmondson, A.C., 2005, 'Failing to learn and learning to fail (intelligently): How great organizations put failure to work to innovate and improve', Long Range Planning 38(3), 299-319.

Capelleras, J.-L., Greene, F.J., Kantis, H. \& Rabetino, R., 2010, 'Venture creation speed and subsequent growth: Evidence from South America', Journal of Small Business Management 48(3), 302-324.

Cardon, M.S., Stevens, C.E. \& Potter, D.R., 2011, 'Misfortunes or mistakes? Cultural sense of making entrepreneurial failure', Journal of Business Venturing 26(1), $1-152$.

Carland, J.C. \& Carland, J.W. (jr.), 2013, 'A model of shared entrepreneurial leadership', Academy of Entrepreneurship Journal 18(2), 71-81.

Chirani, E., Farahbod, F. \& Pourvahedi, F., 2013, 'Entrepreneurship and its importance in organisations', Arabian Journal of Business and Management Review (Oman Chapter) 3(4), 72-76. https://doi.org/10.12816/0016444

Chong, C.H. \& Yeo, K.J., 2015, 'An overview of grounded theory design in educational research', Asian Social Science 11(12), 258. https://doi.org/10.5539/ass. v11n 12 p 258

Christensen, K.S., 2004, 'A classification of the corporate entrepreneurship umbrella: Labels and perspectives', International Journal of Management and Enterprise Development 1(4), 301-315. https://doi.org/10.1504/IJMED.2004.004635

Chuang, Y.T. \& Baum, J.A., 2003, 'It's all in the name: Failure-induced learning by multiunit chains', Administrative Science Quarterly 48(1), 33-59.

Classen, N., Van Gils, A., Bammens, Y. \& Carree, M., 2012, 'Accessing resources from innovation partners: The search breadth of family SMEs', Journal of Small Business Management 50(2), 191-215. https://doi.org/10.1111/j.1540-627X.2012.00350.x

Clohessy, G.R., Holt, D.T. \& Rutherford, M.W., 2007, 'Corporate entrepreneurship: An empirical look at individual characteristics, context, and process', Journal of Leadership and Organisational Studies 13(4), 40-54. https://doi.org/10.1177/107 17919070130040701 
Coleman, S. \& Robb, A.M., 2010, A rising tide: Financing strategies for women owned firms, Stanford Business Books, Stanford, CA.

Collis, J. \& Hussey, R., 2013, Business research: A practical guide for undergraduate and postgraduate students, Macmillan International Higher Education, New York.

Conger, J.A. \& Kanungo, R.N., 1994, 'Charismatic leadership in organizations: Perceived behavioral attributes and their measurement', Journal of Organizational Behavio 15(5), 439-452.

Cox, C. \& Jennings, R., 1995, 'The foundations of success: The development and characteristics of British entrepreneurs and intrapreneurs', Leadership \& Organization Development Journal 16(7), 4-9.

Croitoru, A., 2012, 'Schumpeter, JA, 1934 (2008), The theory of economic development: An inquiry into profits, capital, credit, interest and the busines cycle, translated from the German by Redvers Opie, New Brunswick (USA) and London (UK): Transaction Publishers', Journal of Comparative Research in Anthropology and Sociology 3(2), 1-13.

Dess, G.G. \& Lumpkin, G.T., 2001, 'Linking two dimensions of entrepreneurial orientation to firm performance: The moderating role of environment and industry cycle', Journal of Business Venturing 16, 429-451. https://doi. org/10.1016/S0883-9026(00)00048-3

Dess, G.G., Lumpkin, G.T. \& Eisner, A.B., 2010, Strategic management: Creating competitive advantages, 5th edn., McGraw-Hill, New York.

Dreger, C. \& Zhang, Y., 2011, The Chinese impact on GDP growth and inflation in the industrial countries, DIW Discussion Papers No. 1151, Deutsches Institut fü Wirtschaftsforschung (DIW), Berlin.

Eccles, R.G. \& Serafeim, G., 2013, 'The performance frontier', Harvard Business Review 91(5), 50-60.

Ellis, T.J. \& Levy, Y., 2009, 'Towards a guide for novice researchers on research methodology: Review and proposed methods', Issues in Informing Science \& Information Technology 6, 323. https://doi.org/10.28945/1062

Erickson, S.M. \& Laing, W., 2016, 'The Oxford MBA: A case study in connecting academia with business', Journal of Entrepreneurship Education 19(1), 1.

Farrukh, M., Ying, C.W. \& Mansori, S., 2016, 'Intrapreneurial behavior: An empirical investigation of personality traits', Management \& Marketing 11(4), 597-609. https://doi.org/10.1515/mmcks-2016-0018

Ferguson, T.W., Dougherty, K.D. \& Neubert, M.J., 2014, 'Religious orthodoxy and entrepreneurial risk-taking', Sociological Focus 47(1), 32-44. https://doi.org/10.1 080/00380237.2014.854136

Gillis, W.E., Combs, J.G. \& Ketchen, D.J. (Jr.), 2014, 'Using resource-Based theory to help explain plural form franchising', Entrepreneurship: Theory and Practice 38(3) 449. https://doi.org/10.1111/etap.12008

Gowrishankar, K., 2008, 'Insights into entrepreneurial behaviour in Indian firms', Academy of Entrepreneurship Journal 14(1), 95-105.

Guillemette, M.A., Yao, R., James, I.I.I. \& Russell, N., 2015, 'An analysis of risk assessment questions based on loss-averse preferences', Journal of Financial Counseling and Planning 26(1), 17-29. https://doi.org/10.1891/1052 3073.26.1.17

Gupta, A., Chen, J. \& Gupta, V.K., 2016, 'Does management's attention to different facets of entrepreneurial orientation create value for the firm? A longitudinal study of large retailer', New England Journal of Entrepreneurship 19(2), 54-71. https://doi.org/10.1108/NEJE-19-02-2016-B005

Gusman, Y. \& Febrian, E., 2016, 'The impact of managerial cognition, human capital and social capital on strategic entrepreneurship and firm performance: Evidence from Indonesian Islamic Bank Industry', Academy of Strategic Management Journal 15, 82-94.

Havliček, K., Thalassinos, I.E. \& Berezkinova, L., 2013, 'Innovation management and controlling in SMEs', European Research Studies Journal 16(4), 57-70.

He, F., 2013, 'Learning from failure: The making of entrepreneurial leaders', Doctoral dissertation, The George Washington University.

Hinz, A., 2017, 'Entrepreneurial behaviour revisited: Linking self-efficacy with effectuation', International Journal of Business \& Society 18(S2), 245.

Hisrich, R.D., Peters, M.P. \& Shepherd, D.A. (eds.), 2008, Entrepreneurship, 8th edn., Irwin/McGraw-Hill, Boston, MA.

Hopkins, S.A., Hopkins, W.E. \& Thornton, B., 2002, 'Transforming low-tech environments into high-tech environments: Strategies and developmental barriers', SAM Advanced Management Journal 67(1), 14.

Hornsby, J.S., Kuratko, D.F. \& Zahara, S.A., 2002, 'Middle managers' perception of the internal environment for corporate entrepreneurship: Assessing a measurement scale', Journal of Business Venturing 17(3), 189-290. https://doi.org/10.1016/ S0883-9026(00)00059-8

Inacio, Jr, E. \& Gimenez, F.A., 2012, 'An investigation of the reliability and validity of an entrepreneurial orientation Index in Brazil', Academy of Entrepreneurship Journal 18(2), 41.

Insurance and Pensions Commission, 2013, Annual report, Insurance and Pensions Commission, Harare.

Ireland, R.D., Kuratko, D.F. \& Morris, M.H., 2006, 'A health audit for corporate entrepreneurship: Innovation at all levels: Part II', Journal of Business Strategy 27(2), 21-30.

Israel, D., 2007, 'Research methods for graduate business and social science students', South Asian Journal of Management 14(4), 161.

Jennings, D.F. \& Lumpkin, J.R., 1989, 'Functioning modeling corporate entrepreneurship: An empirical integrative analysis', Journal of Management 15(3), 485-502.
Johannesson, J. \& Jorgensen, P.J., 2017, 'The moderating effect of employee education and professional skills on the relationship between entrepreneurial orientation and performance', Journal of Entrepreneurship Education 20(2), 1-18.

Johnson, D., 2001, 'What is innovation and entrepreneurship? Lessons for larger organisations', Industrial and Commercial Training 33(4), 135-140.

Jones, O. \& Jayawarna, D., 2010, 'Resourcing new businesses: Social networks, bootstrapping and firm performance', Venture Capital: An International Journal of Entrepreneurial Finance 12(2), 127-152.

Jong, J.P.D., Parker, S.K., Wennekers, S. \& Wu, C.H., 2015, 'Entrepreneurial behavior in organizations: Does job design matter?', Entrepreneurship Theory and Practice 39(4), 981-995. https://doi.org/10.1111/etap.12084

Josien, L., 2012, 'Entrepreneurial orientation: An empirical study of the risk propensity dimension of entrepreneurs', Academy of Entrepreneurship Journal 18(1), 21-34.

Kang, W., 2013, 'Does ownership change raise hope for corporate entrepreneurship?', Academy of Entrepreneurship Journal 19(3), 25-41.

Kang, W., 2014, 'A new form of corporate entrepreneurship: Restructuring', Academy of Entrepreneurship Journal 20(3), 40

Kararach, G. \& Otieno, R.O. (eds.), 2016, Economic management in a hyperinflationary environment: The political economy of Zimbabwe, 1980-2008, Oxford University Press, Oxford.

Kilenthong, P., Hultman, C.M. \& Hills, G.E., 2016, 'Entrepreneurial orientation as the determinant of entrepreneurial marketing behaviors', Journal of Small Business Strategy 26(2), 1-22.

Kim, J.Y. \& Miner, A.S., 2007, 'Vicarious learning from the failures and near-failures of others: Evidence from the US commercial banking industry', Academy of Management Journal 50(3), 687-714.

Knight, F.H., 1921, Risk, uncertainty and profit, Hart, Schaffner and Marx, New York.

Knosková, L., 2015, 'Innovativeness processes and entrepreneurial culture for radical innovations', Amfiteatru Economic 17(38), 342-357.

Kreiser, P.M., Patel, P.C. \& Fiet, J.O., 2013, 'The influence of changes in social capital on firm-Founding activities', Entrepreneurship Theory and Practice 37(3), 539-567. https://doi.org/10.1111/etap.12039

Kumar, M., 2007, 'Explaining entrepreneurial success: A conceptual model', Academy of Entrepreneurship Journal 13(1), 57-77.

Kuntze, R. \& Matulich, E., 2016, 'Exploring cognitive bias in entrepreneurial start-up failure', Academy of Entrepreneurship Journal 22(2), 54

Kuratko, D.F., Ireland, R.D., Covin, J.G. \& Hornsby, J.S., 2005, 'A model of middle-level managers' entrepreneurial behavior', Entrepreneurship Theory and Practice 29(6), 699-716.

Kuratko, D.F. \& Hodgetts, R.M. (eds.), 2004, 'Innovation and the entrepreneur', in Entrepreneurship. Theory, process, practice, 6th edn., pp. 138-150, Thomson, Mason, $\mathrm{OH}$

Kuratko, D.F., Hornsby, J.S. \& Goldsby, M.G., 2007, 'The relationship of stakeholder salience, organizational posture, and entrepreneurial intensity to corporate salience, organizational pournal of Leadership \& Organizational Studies 13(4), 56. https://doi.org/10.1177/10717919070130040801

Kuratko, D.F., Montagno, R.V. \& Hornsby, J.S., 1990, 'Developing an intrapreneuria assessment instrument for an effective corporate entrepreneurial environment' Strategic Management Journal 11,49-58, viewed n.d., from, http://ssrn.com/ Strategic Manage
abstract $=1506387$

ee, S.J., 2015, Unraveling the 'model minority' stereotype: Listening to Asian American youth, Teachers College Press, New York.

Leedy, P.D. \& Ormrod, J.E., 2005, Practical research: Planning and design, 8th edn., Pearson Prentice Hall, New Jersey.

Li, Y.H., Huang, J.W. \& Tsai, M.T., 2009, 'Entrepreneurial orientation and firm performance: The role of knowledge creation process', Industrial Marketing Management 38(4), 440-449.

Liang, C. \& Dunn, P., 2014, 'Discovering heterogeneity of entrepreneurs: A comparison of food and nonfood entrepreneurs', Academy of Entrepreneurship Journal 20(2), 19-31.

Liao, J., Kickul, J.R. \& Ma, H., 2009, 'Organizational dynamic capability and innovation: An empirical examination of internet firms', Journal of Small Business Management $47(3), 263-286$

Liao, J., Murphy, P. \& Welsch, H., 2005, 'Developing and validating a construct of entrepreneurial intensity', New England Journal of Entrepreneurship 8(2), 31 https://doi.org/10.1108/NEJE-08-02-2005-B004

Lichtenstein, B.M.B. \& Brush, C.G., 2001, 'How do "resource bundles" develop and change in new ventures? A dynamic model and longitudinal exploration' Entrepreneurship Theory and Practice 25(3), 37-58.

Løkke, A.K. \& Sørensen, P.D., 2014, 'Theory testing using case studies', Electronic Journal of Business Research Methods 12(1), 66-74.

Lubatkin, M. \& Chatterjee, S., 1994, 'Extending modern portfolio theory into the domain of corporate diversification: Does it apply?', Academy of Management Journal 37(1), 109-136. https://doi.org/10.5465/256772

Lumpkin, G.T., Cogliser, C.C. \& Schneider, D.R., 2009, 'Understanding and measuring autonomy: An entrepreneurial orientation perspective', Entrepreneurship: Theory and Practice 33(1), 47

Luzzi, A. \& Sasson, A., 2016, 'Individual entrepreneurial exit and earnings in subsequent paid employment', Entrepreneurship Theory and Practice 40(2), 401-420. https://doi.org/10.1111/etap.12225 
Makinen, G.E., 2017, 'Monetary regimes and inflation: History, economic and political relationships', The Cato Journal 37(1), 167.

McKenzie, B. \& Sud, M., 2008, 'A hermeneutical aprroach to understanding entrepreneurial failure', Academy of Entrepreneurship Journal 14(1), 123-148.

Mir-Babayev, R., Gulaliyev, M., Shikhaliyeva, S., Azizova, R. \& Ok, N., 2017, 'The impact of cultural diversity on innovation performance: Evidence from construction industry of Azerbaijan', Economics \& Sociology 10(1), 78. https://doi. org/10.14254/2071-789X.2017/10-1/6

Montiel-Campos, H., 2018, 'Understanding employees' entrepreneurial alertness: The role of creativity and support for creativity', Academy of Entrepreneurship Journal 24(1), 1-16.

Morris, M.H. \& Sexton, D.L., 1996, 'The concept of entrepreneurial intensity: Implications for company performance', Journal of Business Research 36, 5-13. https://doi.org/10.1016/0148-2963(95)00158-1

Nhavira, J.D.G. \& Ocran, M.K., 2014, 'Measuring the statutory independence of subSaharan Africa central banks', Eastern Africa Social Science Research Review 30(1), 47-72. https://doi.org/10.1353/eas.2014.0002

Nie, W., Dowell, W. \& Lui, A., 2012, In the shadow of the Dragon: The global expansion of Chinese companies-How it will change business forever, AMACOM, New York.

Nieman, G. \& Niewenhuizen, C. (eds.), 2009, Entrepreneurship: A South African perspective, 2nd edn., Van Schaik, Pretoria.

Nouri, P., Imanipour, N., Talebi, K. \& Zali, M., 2018, 'Exploring positive outcomes of decision making biases in the field of entrepreneurial marketing', The Qualitative Report 23(6), 1364-1380.

Ojewumi, A.K., Oyeleke, J.T., Agberotimi, F. \& Adedayo, O., 2018, 'Obafemi Awolowo University undergraduate students: The influence of gender and self-efficacy on entrepreneurial intentions', Journal of Pan African Studies 11(2), 168-186.

Park, M.S., Park, J.W. \& Kim, J.H., 2017, 'The effects of SME CEO's entrepreneurial experience on corporate performance-centred on entrepreneurial failure rate' Academy of Entrepreneurship Journal 23(2), 11.

Phan, P.H., 2004, 'Entrepreneurship theory: Possibilities and future directions', Journa of Business Venturing 19(5), 617-620.

Prosek, J., 2011, Army of entrepreneurs: Create an engaged and empowered workforce for exceptional business growth, AMACOM, New York.

Pickett, J.C., Reilly, D.P. \& McIntyre, R.M., 2005, 'How to select a most efficient OLS model for a time series data', The Journal of Business Forecasting 24(2), 28.

Raffo, D.M., Clark, L.A. \& Arik, M., 2016, 'Strategic responses of non-profit organizations to the economic crisis: Examining through the lenses of resource dependency and resourced-based view theories', Academy of Strategic Management Journal 15(1), 48.

Reserve Bank of Zimbabwe, 2008, 'Monetary Policy Statement' issued in terms of Reserve Bank of Zimbabwe Act, Chapter 22:15, Section 46, Reserve Bank of Zimbabwe, Harare.

Reynolds, P.D., Hay, M., Bygrave, W.D., Camp, S.M. \& Autio, E., 2000, Global entrepreneurship monitor: 200 Executive Report, Kauffman Centre for Entrepreneurial Leadership, Ewing Marion Kauffman Foundation, Kansas City, MO

Russo, M.V., 2010, Companies on a mission: Entrepreneurial strategies for growing sustainably, responsibly, and profitably, Stanford Business Books, Stanford, CA.

Sathe, V., 2003, Corporate entrepreneurship: Top managers and new business creation, Cambridge University Press, Cambridge.

Sar, A.K., 2017, 'Competitive advantage and performance: An analysis of Indian Downstream Oil and Gas Industry', Academy of Accounting and Financial Studies Journal 21(2), M41.

Saunders, M., Philip, L \& Thornhill, A., 2009, Research methods for business students, Pearson Education Limited, London.

Serai, M.H., Johl, S.K. \& Marimuthu, M., 2017, 'An overview on relationship between corporate entrepreneurship and firm performance', Global Business \& Management Research 9, 428

Shane, S. \& Venkataraman, S., 2000, 'The promise of entrepreneurship as a field of research', Academy of Management Review 25(1), 217-226.

Shepherd, D.A., 2003, 'Learning from business failure: Propositions of grief recovery for the self-employed', Academy of Management Review 28(2), 318-328.

Shokri, A., 2012, 'The effects of critical success factors on Iranian industries regarding some entrepreneurial competences and capabilities', Journal of Business Excellence 3(1), 28-32.

Sibanyoni, C. \& Mupambwa, P., 2017, 'Using resource-based theory to examine the competitiveness of an incubation plant in mining and agriculture', International Review of Management and Business Research 6(2), 692.
Singh, R., Squires, J., Fromkin, J.B. \& Berger, R.P., 2012, 'Assessing the use of follow-up skeletal surveys in children with suspected physical abuse', Journal of Trauma and Acute Care Surgery 73(4), 972-976.

Sirmon, D.G., Hitt, M.A. \& Ireland, R.D., 2004, The entrepreneurial mindset, Harvard Business Press, Boston, MA.

Sirmon, D.G., Hitt, M.A. \& Ireland, R.D., 2007, 'Managing firm resources in dynamic environments to create value: Looking inside the black box', Academy of Management Review 32(1), 273-292.

Smith, D., 2010, Exploring innovation, 2nd edn., McGraw-Hill, New York.

Smith, P.R., 2018, 'Collecting sufficient evidence when conducting a case study', The Qualitative Report 23(5), 1054-1048.

Smith, T.A., 2014, 'Testing theory and related factors for influencing proficiency in quantitative research', Academy of Educational Leadership Journal 18(4), 117.

Stockman, C., 2015, 'Achieving a doctorate through mixed methods research', Electronic Journal of Business Research Methods 13(2), 74.

Sun, K.H., 2016, 'Differential impact of uncertainty on exporting decision in risk-averse and risk-taking firms', Seoul Journal of Economics 29, 379-409.

Thomsett, M.C., 2011, The manager's pocket calculator: A quick guide to essential business formulas and ratios, American Management Association, New York.

Todorovic, Z.W., Todorovic, D. \& Ma, J., 2015, 'Corporate entrepreneurship and entrepreneurial orientation in corporate environment: A discussion', Academy of Entrepreneurship Journal 21(1), 82

Trang, N.T.X., 2018, 'Corporate entrepreneurship and firm performance', Advances in Management 11(1), 28-34.

Trujillo, V.J., 2010, 'Research methods in linguistics', Southwest Journal of Linguistics 29(2), 105.

Tse, E. \& Euchner, J., 2017, 'Innovation in China: An interview with Edward Tse. Edward Tse talks with Jim Euchner about China's rising entrepreneurialism and how multinationals can succeed in China', Research-Technology Management 60(5), 15-21. https://doi.org/10.1080/08956308.2017.1348127

Urban, B. \& Gaffurini, E., 2017, 'Organisational learning capabilities as determinants of social innovation: An empirical study in South Africa', SA Journal of Huma Resource Management 15(1), 1-10. https://doi.org/10.4102/sajhrm.v6i1.132

Vance, C.M., Groves, K.S., Gale, J. \& Hess, G.L., 2012, 'Would future entrepreneurs be better served by avoiding university business education? Examining the effect of higher education on business student thinking style', Journal of Entrepreneurship higher education on busin
Education 15(1), 127-141.

Wagner, C., Kawulich, B. \& Garner, M. (eds.), 2012, Doing social research: A global context, McGraw-Hill Higher Education, New York, NY.

Wahyuni, D., 2012, 'The research design maze: Understanding paradigms, cases, methods and methodologies', Journal of Applied Management Accounting Research 10(1), 69.

Wang, K.Y., Hermens, A., Huang, K. \& Chelliah, J., 2015, 'Entrepreneurial orientation and organisational learning on SMEs' innovations', International Journal of Organizational Innovation (Online) 7(4), 71-81.

Wei, X. \& Hisrich, R.D., 2016, 'Error orientation and entrepreneurial decision making in Chinese enterprises: Opportunity identification as mediator', Social Behavio and Personality: An International Journal 44(4), 555-568. https://doi.org/10.2224/ sbp.2016.44.4.555

Welsch, H.P., 2003, Entrepreneurship: The way ahead, Routledge, New York.

Wiklund, J. \& Shepherd, D., 2003, 'Knowledge-based resources, entrepreneuria orientation, and the performance of small and medium-sized businesses', Strategic Management Journal 24(13), 1307-1314.

Wiklund, J. \& Shepherd, D., 2005, 'Entrepreneurial orientation and small business performance: A configurational approach', A Journal of Business Venturing 20, 71-91. https://doi.org/10.1016/j.jbusvent.2004.01.001

Wood, C.C., Holt, D.T., Reed, T.S. \& Hudgens, B.J., 2008, 'Perceptions of corporate entrepreneurship in Air Force organizations: Antecedents and outcomes', Journal of Small Business and Entrepreneurship 21(1), 117-131. https://doi.org/10.1080/ 08276331.2008 .10593416

Zahra, S.A., 2010, 'Harvesting family firms' organizational social capital: A relational perspective', Journal of Management Studies 47(2), 345-366. https://doi. org/10.1111/j.1467-6486.2009.00894.x

Zarutskie, R., 2010, 'The role of top management team human capital in Venture Capital Markets: Evidence from first-time funds', Journal of Business Venturing 25(1), 155-172. https://doi.org/10.1016/j.jbusvent.2008.05.008

Zimmerman, J., 2010, 'Corporate entrepreneurship at GE and Intel', Journal of Business Case Studies 6(5), 77-81. 